Journal of Teacher Education for Sustainability,

vol. 14, no. 2, pp. 73-88, 2012

\title{
TRANSFORMING THE CLASSROOM INTO A REFLECTIVE COMMUNITY: A BLENDED LEARNING INSTRUCTIONAL APPROACH
}

\author{
Nikolaos Dovros and Vassilios Makrakis \\ University of Crete, Greece
}

\begin{abstract}
Critical and reflective thinking is acknowledged as one of the key skills within education for sustainable development whereas sustainable development requires a shift in the mental models which frame our thinking and inform our decisions and actions. This paper describes the implementation of a blended learning lesson unit which aimed at activating pupils' reflective thinking in order to negotiate the controversial topic of genetically modified food (GMF). It describes a small case study that was implemented in a semi-rural school in Chania, Crete, with the participation of 23 pupils from Form 6. Specific changes in the pedagogical practices were adopted, pertaining to content, time and space conventions and the use of online learning activities. The instructional design incorporated a five-stage instructional session, which started by the introduction of a problematic situation, continued with the infusion of cognitive dissonance procedures and ended with a reflective evaluation activity. The pupils' stances towards the open learning procedure and the integration of online activities were positive, while certain changes in their beliefs about the issue of GMF were observed, due to the design of the learning approach.
\end{abstract}

Key words: blended learning, critical thinking, reflective thinking, education for sustainability, problem-based learning

\section{Introduction}

As Meyer (1977) points out, schools are organised networks of socialising experiences which prepare students to act in society. Education is a very important component in the public biography of individuals affecting their life options and paying a crucial role in the formation of their personality. It is also a central element in the general framework of organisation of society, constructing competencies and helping create professions and professionals. Educators who are accustomed to linear approaches in their pedagogy often find it difficult to create truly integrated approaches to learning about sustainability issues due to its multidimensional complexity. With the expansion of the World Wide Web, new paradigms for teaching and learning about such complex issues arise. As a generation of pupils emerges, possessing greater technological knowledge and acceptance, the presence of the internet in 
the classroom will probably increase. This transition requires much more than the development of software devices while its effect on the learning process must be closely examined, especially by the teachers.

Teachers as professionals are charged with the main responsibility of the learning process which can effectively facilitate students' learning and frame their personality traits. According to their pedagogical and philosophical dispositions, teachers perceive education either as a taken-for-granted concept or as a political act that helps pupils liberate their creativeness and promote critical reflection through democratic procedures in the classroom. Political acts reflect power and authority issues. By giving pupils the opportunity to reflect on their experiences and their prior knowledge and by challenging them to question their pre-assumptions rather than urge them to gather information without question, teachers give in authority and power, while pupils take part of the responsibility for their own learning. Should we acknowledge the association between education and society, which necessitates the integration of learning procedures that interact with the world in which learners live, we must admit that there is a need for an alternative pedagogy (Cummings, 2000). A pedagogy that is geared towards creating a society in which humans can live in harmony with their environment and respect the next generations' needs taking into consideration the postmodern reality of uncertainty and complex relationships. Therefore, educators have the choice to transform the classroom into a community that a) develops personal and collective consciousness; b) provides the necessary emancipatory tools and c) engages students in personal and social transformative action (Fernandez-Balboa \& Marshall, 1994; Fernandez-Balboa, 1998). These approaches have in common a recognition that individuals need to foster their abilities in order to reach a state whereby they can take personal responsibility for establishing a reflective practice of their own.

The concept of reflection lacks definitional clarity; yet the core areas of agreement among researchers seem to be that reflection: $a$ ) is a deliberate action; $b$ ) is stimulated by a problematic situation; c) involves an inward examination of personal knowledge with reference to the problem situation and d) leads to new insights (Rogers, 2001; Lim, 2009). Dewey (1997) defined reflection as "active, persistent and careful consideration of any belief or supposed form of knowledge in the light of the grounds that support it and the further conclusion to which it tends" (p. 6). Mezirow (1997) prefers the term 'transformative learning' referring to a procedure that fosters critically reflective thinking and imaginative problem-posing, a structure, in which dialogue is learner-centred, the lesson takes place in participatory and interactive frameworks and involves group deliberation and group problem solving. Mezirow's (1991) model proposes four levels of reflection, the lowest of which is "Habitual action", that is, actions done out of routine practice without having to think about what is done or questioning the grounds for that action. "Understanding" is the next step higher up from "Habitual action". At this level, the learner acts to comprehend what has been learned but does so only within the limits of the given context, without consideration of personal meanings and applications to extend learning. "Reflection", the third step, involves a re-assessment of an 
action or an idea, in light of the problem or situation. When engaged in "Reflection"' learners assess their learning experience, to evaluate their actions for future improvement, as well as consider various possibilities as solutions to problems. However, it is only when learners bring into question the very assumptions and beliefs which underlie their chosen paths of action, the knowledge and ideas which seem to be widely accepted, that "Critical reflection", the final step, is demonstrated.

Critical and reflective thinking is acknowledged as one of the key skills within education for sustainable development (ESD). Sustainable development requires a shift in the mental models which frame our thinking and inform our decisions and actions. Thus, the attainment of sustainable development requires transformative change at social and cultural level; a change that involves experiencing a deep, structural shift in the basic premises of thought, feelings and actions about our being in this world. This requires building the confidence and skills to support engagement among students and the community in order to improve their own and others' lives, livelihoods and environments (United Nations Educational, Scientific and Cultural Organisation [UNESCO], 2011). There is no doubt that achieving sustainable development is essentially a process of learning. Thus, it is important to find out alternative pedagogical frameworks to integrate curriculum, teaching and learning in ways that promote a radical view of ESD that generate economic welfare and social justice within ecological limits (Kostoulas-Makrakis, 2011). Education, therefore, should aim at developing self-paced learning, judgment skills, solidarity, desire for action and critical thinking. Pupils should learn to make judgments and decisions and not simply acquire knowledge in meaningless contexts. They should be given opportunities to test assumptions, juxtapose statements and construct their personal conceptual representations about the world and its relations. It seems likely that this process will have application outside the school and later in their lives (Makrakis \& Kostoulas-Makrakis, 2005). According to Chapter 36.3 of Agenda 21 on Education, Awareness and Training, reorienting education towards sustainable development requires a new vision for education.

Education, including formal education, public awareness and training, should be recognized as a process by which human beings and societies can reach their fullest potential. Education is critical for achieving environmental and ethical awareness, values and attitudes, skills and behaviour consistent with sustainable development and for effective public participation in decision-making. Both formal and non-formal educations are indispensable to changing people's attitudes so that they have the capacity to assess and address their sustainable development concerns (Chapter 36.3, Agenda 21).

During the last decades, constructivist approaches have replaced instructional methods as the focus went away from the teacher and has moved to the individual learner. Learning is seen as a social and collaborative activity that is facilitated rather than directly exerted by the teacher (Paavlova \& Hakkarainen, 2009). Building on theories, where students are involved in knowledge construction and shape their own cognitive representations, social constructivism adds an interactive dimension (Laurillard, 2008). Many researchers have argued that technology 
can serve as a catalyst for such changes in the content, roles and the classroom climate that are required for a shift from instructional to constructivist practices (Collins, 1991; Garner \& Gillingham, 1996). We are entering a new phase in the use of technologies, particularly with the emergence of Web 2.0, which has been identified as a more interactive, peer-generated and collaborative internet. "The new knowledge-based society must be an inclusive society. Here too, the internet offers tremendous possibilities; anyone who can use a computer can participate in society at the click of a mouse" (European Commission, 2002, p. 4). Under these circumstances, e-learning is being more rapidly adopted by educational institutions and has a potential to become a larger part of the educational experience of children as the world moves into a phase that is widely referred to as a knowledge society (Kalantzis, 2004). Web 2.0 tools encompass a variety of different meanings that include an increased emphasis on user generated content, data and content sharing and collaborative effort (Franklin \& van Harmelen, 2007). The rapid evolution of blogs, wikis and other social networking applications offers rich user experiences where the process of knowing is a community-based, collaborative endeavour. Taking into consideration the affordances of these new cutting edge technologies, teachers can organise activities and learning environments that include opportunities for acquiring basic skills, knowledge and conceptual understanding, not isolated in the boundaries of the classroom. Communication channels can be enhanced, and pupils are no more seen as individual learners but rather as more effective participants in the meaningful social practices of their learning communities in school and elsewhere in their lives. To envisage a learning environment outside the confines of the classroom in terms of space and time is to see a social environment undergoing profound change through a tsunami-like flood of innovative tools and services that foster new modes of collaboration and social organisation.

This paper presents an e-learning instructional model which is based on the concept of instructional design. Instructional design is a technology which incorporates known and verified learning strategies into instructional experiences which make the acquisition of knowledge and skills more efficient, effective and appealing (Merrill, 1996). Information and computer technologies do not promote learning per se. They are not multimedia resources that make a difference in training, it is how they are used (Merrill, 1997). We believe that collaboration is developed when the teacher includes activities which are designed to create a social environment that acts as a scaffold for collaborative learning and dialectical constructivism (Palloff \& Pratt, 1999). Taking advantage of the affordances and opportunities that learning management systems (LMS) offer, we attempted to put into practice a learning sequence that expands the boundaries of the traditional classroom in terms of space and time and transforms the pupils into inquirers and reflective practitioners, taking into account their prior knowledge, perceptions and beliefs about a real life problem, such as the proliferation of genetically modified food (GMF). As it is presented more explicitly in the methodology unit, we tried to motivate pupils by challenging them to brainstorm, state their predispositions and search for information and evidence on a dilemmatic issue, by stating, on the one hand, the advantages that GMF offer and, on the other hand, the dangers that they pose using online ac- 
tivities and reflecting in real time face to face discussion sessions. At the final stage, the pupils were asked to contemplate on the facts and information they had found and their personal dispositions and give their point of view without trying to suggest a solution. The window of learning was kept half open. The aim of this study was to examine if reflective thinking through blended learning procedures, with the use of LMS, can be an effective approach in order to infuse problem-based learning sequences in primary education.

\section{Methodology}

In order to involve pupils in reflective action, we chose to negotiate the topic of GMF. The main goal of this project was not to instruct pupils on the issue, but to set the grounds to promote reflection. Over the past half-century, there has been a shift among philosophers and sociologists of science, away from seeing science as a purely empirical process, to seeing it as a social process of knowledge construction in which imagination and argument play an important role (Seethaler \& Linn, 2004). It is our belief that reflective thinking can be promoted through controversial issues that pupils encounter in their everyday lives although we acknowledge that contents pay a crucial role in the procedure by framing the learning sequence and helping pupils stay focused. Contents are the vehicles that lead to reflective action; the procedures are the main characteristics that help nurture reflective and critical thinking. Therefore GMF was chosen because a) it is a topic that students encounter in their everyday lives; b) it is a highly controversial issue with ethical, religious and political dimensions; $c$ ) it is a topic that shapes a sustainable future in agriculture, health and economy; d) it offers opportunities for dialogue, juxtaposition and reflection. The instructional model proposed is based on the principles of problem-based learning. The ability to apply our thinking and draw on a range of resources to solve complex real-life problems is, in our opinion, a basic principle of education. Simons and Ertmer (2006) suggest that problem-based learning designs are characterised by students' engagement with ill-structured problems, introduction of the problem prior to acquisition of relevant content knowledge, collaboration, instructional support during the problem-solving process and the facilitation of learner reflection.

\section{Procedure and tools}

This small case study was conducted at a primary school at the suburbs of Chania, Crete, with the participation of 23 pupils from Form 6,12 girls and 11 boys. The great majority of the pupils were very well acquainted with the use of internet tools as 19 of them (ten girls and nine boys) possessed a computer at home and had broadband internet access while the others had received instruction at school during the previous year since ICT, as a subject, is part of the school's curriculum. The learning procedure lasted approximately four weeks, at the beginning of the school year 2011/2012, from September 19 to October 20, 2011. Specifically, we dedicated eight school hours, four two-hour sessions, including an hour to present the learning environment, through which the learning procedure would take place. That is 
learning activity management system (LAMS).

LAMS is an open source online learning environment for educators which affords them with means to design, manage and deliver online collaborative learning activities. LAMS development began in 2002 by Macquarie University in Australia and was released as open source software in 2005. It is now supported by a wide learning community (http:// lamscommunity.org), and it can be used either as a stand-alone system or in conjunction with other LAMS, such as Moodle, Sakai, Blackboard, etc. It can support a wide range of pedagogical approaches giving the opportunity to educators to select the activities that match their preferred style. The activities can include a variety of individual tasks, small group work or whole class activities based on both content and collaboration. By using such new generation learning design tools, learners - whatever their preferred learning style - may become actively engaged and challenged. Once a sequence is proved to be effective, it can be redistributed for use in different contexts through an active online community, thereby creating a repository of effective templates. Taking advantage of the shared experience and creativity, instructors can save time and reduce the workload necessary for planning and developing e-learning sequences. LAMS provides three environments in order to a) author learning sequences (author's environment); b) implement them (learner's environment) and c) monitor the learners' online activities (monitor environment).

\section{The instructional module}

The instructional module which was implemented encompasses four consecutive instructional components followed by an evaluation activity. The four components were the following: problem presentation, prior knowledge activation, dilemmatic negotiation, synthesis and evaluation.

The learning setting included an online animation character, Sifis the panda, which urged pupils to join him in his quest to unravel the controversies of GMF. Pupils would write down their ideas, prior knowledge, opinions and arguments in online forums, online question and answer activities and vote for or against certain statements related to GMF. Taking the pupils online comments as primary raw material, the teacher would establish an open dialogical framework in the classroom, in order to stimulate the pupils' imagination and high-order thinking skills. The teacher was a facilitator, a person who would encourage pupils to brainstorm, express arguments, challenge and stimulate heretic points of view, scaffold and foster metacognition. The online environment helped give voice to all pupils and create a starting point for face-to-face dialogue and argumentation taking advantage of both online and faceto-face practices. The pedagogical framework had the characteristics of blended learning approaches.

\section{Blended learning, a combination of face-to-face and online procedures}

The Web is increasingly used as a resource in $\mathrm{K}-12$ education. Almost all the schools in 
Greece are connected to the internet, and the Ministry of Education encourages the use of internet in education. Yet, the communicative aspect of the web has received little attention among teachers of the Greek primary and secondary education sectors (Papastergiou \& Solomonidou, 2005; Aslanidou \& Menexes, 2007). Today, children can browse the internet and search for resources, communicate and share ideas with their schoolmates and teachers, upload assignments and conduct research. Taking advantage of the new Web 2.0 technologies, teachers, on their side, can seize opportunities of transferring part of the learning workload outside the physical boundaries of the classroom at an online environment. Online learning has its drawbacks, the main of which is the lack of physical and emotional interaction, something that is taken for granted in conventional learning settings. The need for a compromise between the conventional face-to-face settings and online learning led to blended learning, a new approach to teaching and learning.

Blended learning should be viewed as a pedagogical approach that combines the effectiveness and socialisation opportunities of the classroom with the technologically enhanced active learning possibilities of the online environment (Dziuban, Hartman, \& Moskal, 2004). It converges online and face-to-face education, providing opportunities to foster reflective thinking, facilitate communication and collaboration, give voice to all the pupils, extend the lesson in space and time, help the construction of knowledge through inquiry-based activities and promote learner control, through open learning environments. For a learning environment to succeed, teachers need to change their traditional role of information delivery to effective scaffolding that supports students in integrating and applying ideas. In this type of learning environment, students also undertake new roles. The main characteristics of blended learning are (Dziuban et al., 2004):

- a shift from lecture to student-centred instruction in which students become active and interactive learners;

- increases in interaction between student-instructor, student-student, student-content and student-outside resources;

- integrated formative and summative assessment mechanisms for students and instructor.

\section{The learning journey}

The pedagogical framework chosen is in tune with the characteristics of Kostoulas-Makrakis (2011) process for radical sustainability transformation which focuses on procedures that radically revise our view of learning. From a process which acts on individuals' characteristics in order to change the world to one which challenges individuals' views of the world as a means of influencing their characteristics and hence ways of thinking and living (Huckle, 2006). According to Kostoulas-Makrakis (2011), the four interactive stages are entailed in the pedagogical perspective that fosters reflection within the context of radical sustainability transformation (Figure 1):

1. getting started (reflection, activation, problem identification and problematisation, 
disorienting dilemma);

2. de(re)construction (reflection, reformulation, reassessment);

3. getting involved (reflection, knowledge construction, transformation);

4. learning-based change (learning by action, change).

Through this model, the learner is viewed as an active agent in a change process. Participants get engaged in discourse and critical self-reflection, using various activating events and disorienting dilemmas, through which they come to critically examine their personal views and, therefore, open themselves to alternative views and practices.

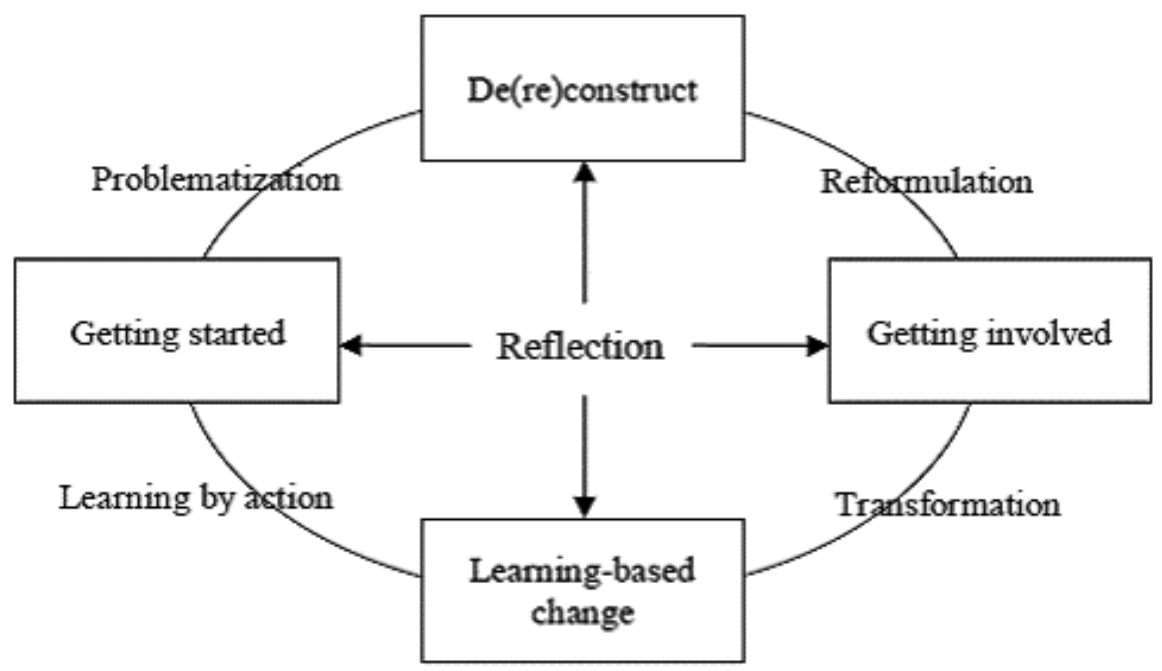

Figure 1. A methodological approach to infuse a radical view to education for sustainability (Kostoulas-Makrakis, 2010)

After dedicating one school hour in order to familiarise pupils with LAMS, each pupil entered the learner's environment with his/her codes. The first learning component called "Presenting the problem-Motivation" included an introductory narration, which aimed to introduce the topic and motivate pupils to express their ideas. An animation character, a panda introduced itself and asked pupils to join in an inquiry and reflective journey about GMF (Figure 2). The animation helped to create a friendly and safe environment, trying to motivate pupils. The educator then asked the pupils to say what they knew about the topic in face-to-face settings, creating a starting point for the procedure. 


\section{Eıoaywyí}

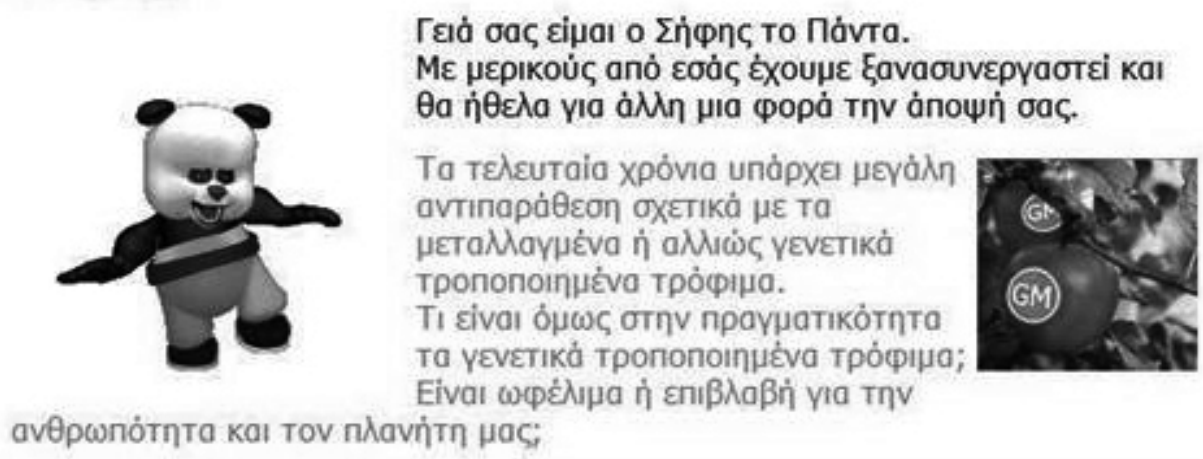

Figure 2. Presenting the problem - motivation

The second component, called "Prior knowledge activation", integrated an online forum where pupils would share their knowledge about the topic, brainstorm and express their first arguments about GMF. The conventional setting of the classroom does not offer enough time so that everyone can contribute to the dialogue. Inevitably, pupils that are introverted or have not acquired adequate language skills seldom participate. Forums give the opportunity for pupils to take their time, contemplate on their classmates' comments and voice their points of view. They can answer at a specific comment or express an alternative view in collaborative settings. The online dialogical framework gave a starting point to expand the conversation in the classroom where the teacher can provoke cognitive dissonance and challenge the pupils to reason and think critically. The teacher did not, under any circumstance, reveal his dispositions towards the topic asking the pupils to express freely their opinion and encouraging them to search for evidence. Almost all the pupils tried to acquire data from the internet, while some asked their family to enlighten them about the issue. Negative predispositions prevailed, while the alteration of the DNA chain and the negative effect such products have on health were the main characteristics mentioned.

The third component, called "Dilemmatic negotiation", on the one hand, offered a scaffold to pupils by presenting specific core data about GMF, but, on the other hand, asked them to make decisions that are for or against them. It was consisted of four activities, all online.

1. Resources for GMF. Presenting basic facts advocating use and proliferation of GMF. The main arguments that advocated them were the following: 1) Mankind has been modifying genes for thousands of years in breeding; 2) The world can be saved from global famine through greatly improved crops; 3) GMF can be pest or disease resistant and reduce or eliminate the need to use pesticides or herbicides.

2. Voting activity. After contemplating upon the given facts, pupils vote if they are predisposed for, against or if they are not sure about GMF. The options available were: a) I believe that GMF are unfairly accused and should be seen with an optimistic view; b) I believe that GMF are dangerous for humans' health and the 
environment, therefore they should be banned; c) I'm not sure yet, I need more evidence.

3. Resources against GMF. Presenting facts that oppose GMF use and proliferation. The main arguments posed against them were: a) They have been proved to be detrimental for human health; b) They could lead to even stronger and resistant pests that would necessitate even stronger pesticides; c) It is unethical to intervene in the nature's function; d) The main motive for GMF development is people's arrogance and lust for money.

4. Voting activity. Applying the same voting activity to challenge pupils' views about the issue, after seeing the opposite point of view. It was interesting to see whether pupils would change their first options.

The aim of this component was to cause cognitive dissonance and push pupils to think and critically evaluate their options. The results of the voting activities are depicted in Figure 3. There was a shift in the pupils' choices from the first voting activity to the second. At first, many pupils, influenced by the facts that advocated GMF, were sceptical about the use of such products. Specifically, $13.04 \%$ (3 pupils) voted for them, $47.82 \%$ (11 pupils) voted that they are dangerous for humanity, while $39.13 \%$ (9 pupils) were reluctant to adopt a clear stance. After reading the arguments that opposed GMF, there was a great shift towards opposing them as $73.91 \%$ ( 17 pupils, a rise of $26.09 \%$ ) voted that they are dangerous for humanity. Only 4 pupils (17.39\%, a decline of $21.74 \%$ ) did not adopt a clear stance. Most of those that voted for GMF (2 out of 3) still kept their option.

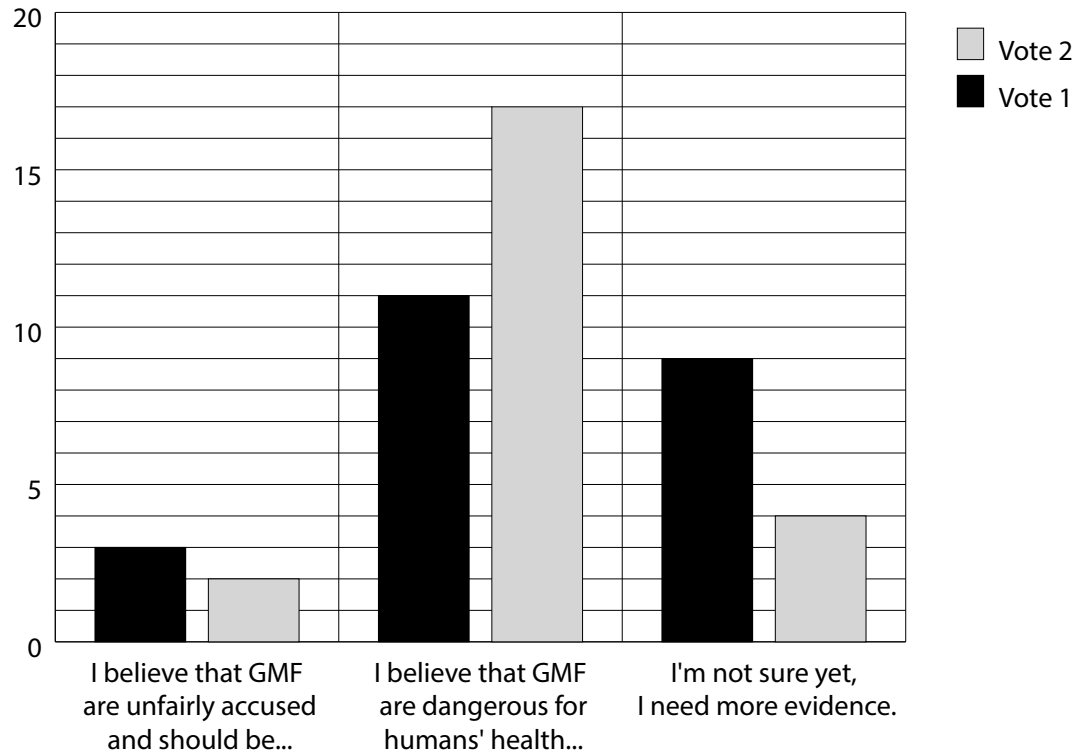

Figure 3. Results of the two voting activities 
The last component called "Synthesis" included two online activities followed by a discussion phase in the classroom. Having acquired a first-order knowledge about the topic, the pupils were fostered to search for more details through the internet. The pupils were divided in groups of four and fulfilled the two activities within their subgroups. The two activities were:

1. Searching for resources about GMF. LAMS offers a "Share resources" activity, which offers the ability to navigate the internet and propose URLs with digital resources, such as web pages, videos, online documents and blogs that can be shared among the other learners. Pupils act as nascent researchers, practising searching, elaborating and evaluating data skills.

2. An online Question and Answer activity that asks pupils to write down their points of view about GMF, having conducted their own research. The question posed was: Depending on the information you have gathered, state your personal opinion, whether GMF are dangerous for humanity and the environment or if there are some advantages that should be taken into consideration. The answers could be viewed from all the members of the subgroups in order to provoke dialogue and communication.

The pupils proposed a wide range of resources including text, pictures and videos while their answers denoted the fact that GMF could become a plague for humanity and our planet. Through the final conversation in the classroom, the common conclusion, which was unanimously accepted, was that although there could be found some arguments that advocate GMF by weighing the tradeoffs, it is difficult to predict the long-term effects of GMF, which, at this time, seem to be catastrophic and lead to a road with no way back.

The tools used to evaluate this intervention were a) the teacher's observations, who acted as an insider, and b) the e-portfolio of the class, a tool offered by LAMS, which is a compressed folder with all the online interactions of the e-classroom. We ended the lesson by posing a reflective question that asked the pupils to write down their impressions about this innovative form of lesson.

Today, despite the web revolution, learning in Greek schools is still pursued inside the walls of the classroom; pupils are rarely challenged to contemplate on what they learn, while communication is basically achieved between those that are in tune with the existing culture and are rather extroversive. And it is not always the teachers' choice to adhere to such approaches, but a 45-minute lesson does not offer enough time for pupils with different learning styles to exert communicative abilities and practice reflective skills. Online activities offer time to contemplate on what each pupil wishes to say. They open the lesson outside the classroom walls while the infusion of face-to-face activities through blended procedures advances the interactive stance of the lesson. The characteristics of our reflective blended learning approach in comparison with the conventional settings of the everyday lesson in the classroom, according to what the author has elicited from the pupils, are depicted in Table 1. 
Table 1. A comparison of conventional and the blended-learning reflective classroom settings

\begin{tabular}{lll}
\hline Characteristics & Conventional lesson & E-learning reflective approach \\
\hline Space and time & $\begin{array}{l}\text { The lesson is given in the } \\
\text { classroom, throughout the } \\
\text { school hour }\end{array}$ & $\begin{array}{l}\text { The lesson is conducted either in the } \\
\text { classroom and at home or in the schools } \\
\text { laboratory. Pupils enter the online } \\
\text { environment at any convenient time. They can } \\
\text { fulfil collaborative activities from home }\end{array}$ \\
\hline Self-paced learning & $\begin{array}{l}\text { Learners have to fulfil } \\
\text { their assignments in the } \\
\text { given time or respond } \\
\text { to conversations in the } \\
\text { classroom settings }\end{array}$ & $\begin{array}{l}\text { Pupils take their time, communicate through } \\
\text { the asynchronous online tools and fulfil their } \\
\text { assignments according to their personal pace }\end{array}$ \\
\hline $\begin{array}{l}\text { In the classroom, time is not } \\
\text { sufficient for every pupil to } \\
\text { express their point of view, } \\
\text { so introverted individuals } \\
\text { usually stay on the fringe }\end{array}$ & $\begin{array}{l}\text { Dialogue is enhanced through multivariate } \\
\text { communicative paths. It is commenced } \\
\text { through online forums and conversations and } \\
\text { is expanded in face-to-face settings. Every } \\
\text { pupil has expressed his/her opinion in such } \\
\text { online tools, so the teacher can make use and } \\
\text { encourage introverted individuals, as he/she } \\
\text { has at his/her disposal the written comments } \\
\text { of all pupils }\end{array}$ \\
\hline Contents & $\begin{array}{l}\text { Pupils reproduce the given } \\
\text { contents. Reproduction is } \\
\text { the aim of the typical lesson }\end{array}$ & $\begin{array}{l}\text { Pupils search for data by themselves; they are } \\
\text { challenged to test their validity, construct and } \\
\text { give meaning to what they have read. There is } \\
\text { no one solution to the problem; the window } \\
\text { of knowledge is always kept half-open. } \\
\text { Contents are the vehicles for reflection and } \\
\text { metacognition }\end{array}$ \\
\hline Articulation & $\begin{array}{l}\text { Pupils have to express } \\
\text { given facts and knowledge, } \\
\text { according to the school book }\end{array}$ & $\begin{array}{l}\text { Pupils express their own points of view } \\
\text { without fearing to be wrong. Emphasis is } \\
\text { given to why they express an idea, how they } \\
\text { reached a conclusion, how they feel about it } \\
\text { and what were the criteria for their choices }\end{array}$ \\
\hline
\end{tabular}

The most common answers that pupils gave to the evaluation question at the end of lesson were that they liked this kind of lesson because it involved computer and internet use. They characterised it as an enjoyable style to give lessons and asked when they were going to do something alike. GMF was a topic that activated them and agitated them, especially when arguments that advocate the use of such products were presented. Furthermore, we should point out some observations that concerned us:

1. Pupils' written contributions to the forums and 'question and answer' activities lacked language wealth. They were simple sentences with not enough arguments that supported their option, although their oral contributions were much more elaborate.

2. Most pupils entered the online environment at school with the presence of the teacher rather than at home. The reason for this, according to their responses, was that they felt insecure about doing something wrong.

It seems that the passage from the closed conventional learning settings to a more open 
environment takes time. Some pupils even did not know what to do after completing an activity since they did not read the instructions given. Self-paced learning has its own logic and requires activating certain skills, such as reading instructions.

\section{Conclusion}

The instructional model described in this paper was designed to help pupils come to an integrated understanding of the GMF controversy. The issue had the potential to activate pupils' reflective practices and make them think about issues that relate to their health and the environment in which they are going to act as citizens. By contemplating on their beliefs, juxtaposing statements and reconstructing their dispositions, they acquired the basic skills needed for creative citizens that live in a world that changes. Making sustainable choices necessitates the adoption of certain stances towards the self and the community, and this cannot be attained through didactic or lecture practices. Children have to be immersed in learning practices that urge them to search for data, cross-examine their validity, contemplate on the impacts of their choices and take action. This leads to a transformation of the classroom from a place were taken for granted knowledge is transmitted into a place where everything is put in question. And this cannot be achieved inside the four walls of a classroom. Dilemmatic topics, such as GMF, offer all the preconditions to achieve such skills. The teacher must struggle not to give answers to pupils but leave them to construct their points of view and give meaning to their choices. Scaffolding questions such as: Why do you say that? How do you feel about this? and How did you reach that conclusion? can trigger their critical skills and keep them focused, while supportive data should be given after they have stated their prior knowledge and predispositions. It is important to make the class discuss, juxtapose and respect other opinions. This could be achieved if pupils had time to contemplate and discuss with the community and their family. LMS and open e-learning environments can broaden the classroom's settings and give space to such perspectives. In this study, we were given the impression that pupils activated themselves about GMF by involving their families. For at least three months, we were bombarded with questions and comments which were derived from discussions with their parents concerning advertisements and journals about GMF as well as consumption practices.

Transformative and critical constructivist learning is a shift of consciousness that involves an understanding of a) one's self in the world; b) relationships with others and the natural world; c) the relations of power; d) alternative approaches to living and e) the possibilities for social justice, peace and personal joy (Kostoulas-Makrakis, 2011). A critical constructivist perspective of learning incorporates social negotiation, which recognises that learners learn by challenging their thoughts, beliefs, perceptions and existing knowledge through interacting with other learners and applying reflective practices in the classroom. 


\section{Acknowledgement:}

This work has been developed within the framework of the ICTeESD project that has been funded from the European Commission (ERASMUS Multilateral Programme Virtual Campus Project No. 510212-LLP-1-2010-1-GR-ERASMUS-EVC (2010-3494). The content of the paper reflects the views of the authors, and the Commission cannot be held responsible for any use which may be made of the information contained therein.

\section{References:}

Aslanidou, S., \& Menexes, G. (2007). Youth and the Internet: Uses and practices in the home. Computers \& Education, 51, 1375-1391.

Collins, A. (1991). The role of computer technology in restructuring schools. Phi Delta Kappan, 73, 28-36.

Cummings, J. (2000). Academic language learning, transformative pedagogy, and information technology: Towards a critical balance. TESOL Quarterly, 34(3), 537-548.

Dewey, J. (1997). How we think. New York: Dover Publications Ink.

Dziuban, C., Hartman, J., \& Moskal, P. (2004). Blended learning. Educause, 7, 1-12.

European Commission. (2002). Towards a knowledge based Europe. The European Union and the information society. Retrieved April 16, 2009, from http://ec.europa.eu/publications/ booklets/move/36/en.pdf

Fernandez-Balboa, J., \& Marshall, J. (1994). Dialogical pedagogy in teacher education: Toward an education for democracy. Journal of Teacher Education, 45(3), 172-182. DOI: $10.1177 / 0022487194045003003$.

Fernández-Balboa, J. (1998). The practice of critical pedagogy: Critical self-reflection as praxis. Teaching Education, 9(2), 47-53. DOI: 10.1080/10476210.1998.10335494.

Franklin, T., \& van Harmelen, M. (2007). Web 2.0 for content, for learning and teaching in higher education. London: Joint Information Systems Committee.

Garner, R., \& Gillingham, M. G. (1996). Internet communication in six classrooms: Conversations across time, space, and culture. New Jersey: Lawrence Erlbaum Associates.

Huckle, J. (2006). Education for sustainable development: A briefing paper for the training and development agency for schools. Retrieved July 16, 2008, from http://www.ttrb.ac.uk/ Browse2.aspx? anchorId=14633\&selectedId=14634

Kalantzis, M. (2004). Diversity, new technologies and new learning. Paper presented at an international conference on computers in education, RMIT, Melbourne, Victoria, Australia.

Kostoulas-Makrakis, N. (2011). Developing and applying a critical and transformative model to address education for sustainable development in teacher education. Journal of Teacher Education for Sustainability, 12(2), 17-26. DOI: 10.2478/v10099-009-0051-0. 
Laurillard, D. (2008). The pedagogical challenges to collaborative technologies. ComputerSupported Collaborative Learning, 4, 5-20. DOI: 10.1007/s11412-008-9056-2.

Lim, L. Y. L. (2009). A comparison of students' reflective thinking across different years in a problem-based learning environment. Instructional Science, 39(2), 171-188.

Makrakis, V., \& Kostoulas-Makrakis, N. (2005). Techno-sciences and mathematics: Vehicles for a sustainable future and global understanding. Proceedings of the 2nd International Conference on Hands-on Science (pp. 103-108). Crete: University of Crete.

Merrill, M. D., Drake, L., Lacy, M. J., Pratt, J., \& ID2 Research Group. (1996). Reclaiming instructional design. Educational Technology, 36(5), 5-7.

Merrill, M. D. (1997). Instructional strategies that teach. CBT Solutions, Nov./Dec., 1-11.

Meyer, W. J. (1977). The effects of education as an institution. American Journal of Sociology, 83(1), 55-77.

Mezirow, J. (1991). Transformative dimensions of adult learning. San Francisco: Jossey-Bass.

Mezirow, J. (1997). Transformative learning: Theory to practice. New Directions for Adult \& Continuing Education, 74, 5-12.

Paavlova, S., \& Hakkarainen, K. (2009). From meaning making to joint construction of knowledge practices and artefacts: A trialogical approach to CSCL. Proceedings of the 9th International Conference on Computer Supported Collaborative Learning (pp. 83-92). Kallithea: International Society of the Learning Sciences.

Palloff, R., \& Pratt, K. (1999). Building learning communities in cyberspace: Effective strategies for online classroom. San Francisco: Jossey-Bass.

Papastergiou, M., \& Solomonidou, C. (2005). Gender issues in Internet access and favourite Internet activities among Greek high school pupils inside and outside school. Computers \& Education, 44(4), 377-393.

Rogers, R. R. (2001). Reflection in higher education: A concept analysis. Innovative Higher Education, 26(1), 37-57.

Seethaler, S., \& Linn, M. (2004). Genetically modified food in perspective: An inquiry-based curriculum to help middle school students make sense of tradeoffs. International Journal of Science Education, 26(14), 1765-1785.

Simons, K. D., \& Ertmer, P. (2006). Scaffolding disciplined inquiry in problem-based learning environments. International Journal of Learning, 1(6), 297-305.

UNESCO (United Nations Educational, Scientific and Cultural Organisation). (2011). Education for sustainable development. An expert review of processes and learning. Paris: UNESCO. 


\section{Correspondence:}

Nikolaos Dovros, PhD, Department of Primary Education, University of Crete, 74100, Rethymnon, Crete, Greece. Email: dovrosn@yahoo.gr 